\title{
John Douglas and the Asian Presence on Thursday Island: 1885-1904
}

Jeremy Hodes

Torres Strait during the colonial era was synonymous with the name of John Douglas, who, as its Government Resident, ruled this remote and far-flung administration. Here was the last great Australian imperialist — devising, implementing and maintaining an administrative apparatus for the region and its people that was paternalistic, benevolent and autocratic. In this task, he was guided by the principles of 'providential duty, the destiny of race, and the other lofty abstractions of late Victorian imperialism'.1

That he was able to rule Torres Strait as a sort of 'constitutional sovereign' 2 for the benefit of its inhabitants, according to his own liberal beliefs, tenets and values, possessing unbounded moral and statutory authority, ${ }^{3}$ was without parallel in Queensland colonial history. While he was aided and abetted in this by the geographical remoteness of Torres Strait, it was also due in 
large part to his undoubted administrative ability, coupled with his extensive political connections and experience. Douglas brooked no interference in his domain and indeed encountered little, being left largely to his own benevolent devices by his grateful political masters in far-off Brisbane. This chapter will examine his interaction with Asian peoples on Thursday Island, particularly the Japanese, his attitudes towards them, and his impact on their lives. In order to better understand his role and influence, it is necessary to briefly examine his life and career prior to his arrival in the region.

\section{Hon. John Douglas: his formation and early career}

John Douglas was born in London on 6 March, 1828, a nephew of the Marquess of Queensberry. Educated at Rugby and Durham University, he came to NSW in 1851, working as a sub-commissioner of crown lands and magistrate on the goldfields, before purchasing Talgai on the Darling Downs. He represented the Downs and Camden districts in the NSW Parliament before purchasing the property, Tooloombah, in the Rockhampton district. Elected to the Queensland Parliament as the Member for Port Curtis in 1863, he first entered the ministry in 1866 as Postmaster General. In 1869, he was appointed to the post of AgentGeneral for Emigration to the Colony of Queensland in England. He returned to Queensland in 1871, re-entered parliament in 1875, becoming Minister for Lands in 1876 and Premier from 1877 to 1879 , before retiring from parliament and becoming a leader writer for the leading Queensland newspaper, the Brisbane Courier.

His role in the genesis of European settlement and administration in Torres Strait was profound, beginning in 1866, when, on his recommendation as Postmaster General, the Torres Strait mail service first began. In 1877, under his premiership and on his initiative, the Queensland Government established the administrative settlement of Thursday Island, ${ }^{4}$ Douglas travelling to Torres Strait later that year on an official visit of inspection. ${ }^{5}$ In 1879 , at his insistence, the maritime boundary of Queensland was extended to include all islands of Torres Strait and, on 13 April, 1885, he was appointed as the first Government Resident for Thursday Island. He held this position until his death, nearly 20 years later, aged 76, on 21 July, 1904. From 27 December, 1885, to 3 September, 1888, he also served as Special Commissioner for the protectorate of British New Guinea, administering the territory preparatory to it being formally proclaimed a crown colony.

At the time of his appointment, Thursday Island was a small, isolated settlement, the population of which consisted of a few Europeans, with pearling the main industry, employing Europeans, Filipinos, Malays and Pacific Islanders. 
By the end of the century, it had become a multiracial, multi-ethnic, cosmopolitan outpost, the commercial and administrative centre for Torres Strait, with the pearling industry dominated numerically by Japanese. An 1899 visitor to this 'Insular Babel' found:

Europeans, about half a dozen nationalities, Chinese, Japanese, Javanese, New Guinea men, South Sea Islanders, including Rotuma boys, who are much esteemed, and Tanna boys, who are esteemed less, Manilamen, Mauritius blacks, Hindoos from British India, from Goa, from Pondicherry, Australian mainland blackfellows (here called Binghis), Australian island blacks from places like Prince of Wales Island, Goode Island, and Jervis Island or Mabuac [sic], and American and West Indian Negroes. ${ }^{6}$

Douglas, already 56 years of age when he settled on the island, cut a commanding presence as the benevolent older statesman:

Bearded like winter, and his plentiful white hair covers the large area of his head in wavy undulations, almost to be described as ringlets. He is ... a large man, and his keen eyes scintillate with that immense sagacity regarding men and things which is the characteristic of veteran politicians. His voice is deep and clear. His utterances come forth in well mannered periods, the concluding word of each one of which was strongly emphasised, as if he were clinching every point in an argument against some redoubtable oratorical opponent. But with it all was the mellowing which comes with age. ${ }^{7}$

Like many Victorians, Douglas had strong views on race and class. A lifelong adherent to the concept of liberalism, he supported the underdog and those trying to improve their status. He consistently opposed the importation of Pacific Islanders to the sugar industry in Queensland, considering it to be little better than slavery. Under his premiership, Polynesian immigration was restricted. As Government Resident, he was particularly concerned for the welfare of Torres Strait Islanders, and it was mainly due to his efforts that they did not come under the Aboriginals Protection and Restriction of the Sale of Opium Act of 1897, but were considered a group separate from Aborigines and were better treated. That they held a special place in his heart is evident from this impassioned plea in 1900:

The native-born population are British subjects. They are civilised people; they are being educated, and they are entitled, and I say, should be treated as British subjects. Still they are not enumerated even in the census. I hope that in any future census notice will be taken of them ... They are human beings; they are our own flesh and blood; they are born under our 
jurisdiction; and they are entitled, I maintain, to the privileges we enjoy ... The natives of the islands of Torres Strait are capable of exercising all the rights of British citizens, and they aught to be regarded as such. ${ }^{8}$

Douglas had no antipathy to individual Asians. He counted the Chinese mandarin, Quong Tart, among his friends, ${ }^{9}$ he helped a destitute Malay return home to Singapore, ${ }^{10}$ and was the sole European attending a reception put on by the Japanese Brethren Society for the Townsville-based honorary Japanese consul, K. Iijima. ${ }^{11}$ When it came to groups that were deemed to threaten the British way of life in colonial Queensland, however, Douglas had a very different response. As premier, he halted Chinese immigration into Queensland in 1877 , to popular acclaim; in the 1890s, he played a major part in restricting and regulating Japanese immigration into Torres Strait. In doing this, he was not motivated primarily by considerations of race, but rather by a desire to keep Queensland a colony in which British values and the British way of life were paramount. Douglas had no desire to see his adopted land go the way of Hong Kong or Singapore. Although a proud 'White Australian' and a devout Anglican who strived to do his best for all, he, like many 19th-century liberals, maintained that 'the distinction of colour or creed should not exist for us, so long as we secure the rightful ascendency of our race'. ${ }^{12}$

\section{Douglas and the Japanese}

Douglas's main interaction with Asians was with the Japanese, who, through their overwhelming numbers, dominated the fishing industry in Torres Strait. His early years were devoted to restricting Japanese immigration and influence, his later years to ensuring that they abided by the regulations and legislation governing the pearl-shelling industry. As a police magistrate, he was involved in upholding the peace and meting out justice, and this he did without fear or favour.

One celebrated instance of Douglas's impartiality in dispensing justice concerned the arrest of a Japanese diver, Nakane, for indecency and resisting arrest on Thursday Island in January 1898. The arrest was made under what appeared to be difficult circumstances, with 200 of his countrymen present. The case was heard before Douglas over four days, with several hundred Japanese attending. Douglas found that Nakane was indeed guilty of indecent exposure, for urinating in public on a Saturday afternoon in the main thoroughfare while under the influence of liquor. He called, however, for discretion on the part of police, noting that not only were there no urinals there, but that 'I have also myself urinated in a public street, though of course in a quiet corner, and never felt that I had committed an act of indecency'. ${ }^{13}$ 


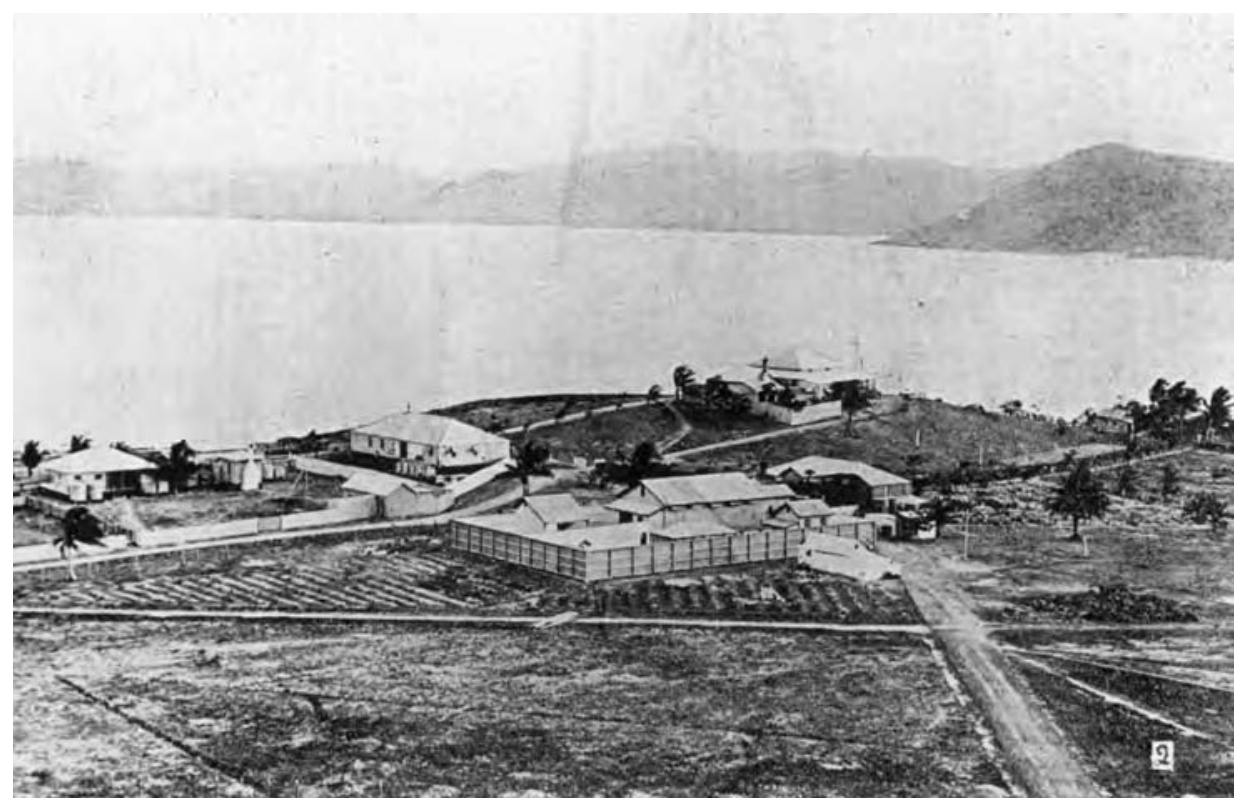

Government buildings, Thursday Island, 1897.

Courtesy of John Oxley Library, Brisbane (Item No. 11962).

While agreeing that Nakane resisted arrest, Douglas refused to record a conviction on this count, instead criticising the police for their excessive use of force, the constable having 'downed him [Nakane] a second time in a rather inhuman manner, and knocked him senseless'. ${ }^{14}$

This verdict caused a storm throughout the colony, the local paper saying it all in its choice of subheadings when reporting the case:

A charge of Indecency: Extraordinary decisions: The police snubbed: The lawbreakers complimented. ${ }^{15}$

A contemporary, writing under the nom de plume 'Old Colonist', went much further, using this case as an illustration of how Thursday Island had fallen into the 'hand of the Japs'.

In a recent riot case in which the Japanese had been the delinquents, legal proceedings were taken by the police. The case was heard in the local court before the government resident, who is also police magistrate. This functionary is reported as being so overawed by the overwhelming number of Japanese, in and around the court, interested in the case, that he was unable to administer strict justice through lack of power to enforce his decision and uphold the authority of the court, and to prevent a possible outbreak a paltry fine of 20s. was imposed, instead of a sentence of six months' imprisonment. ${ }^{16}$ 
The first Japanese came to Torres Strait in the 1870s, seeking work in the pearling industry. ${ }^{17}$ They were employed as divers, performing so well that employers preferred them to other groups. From 1891, Japanese merchants facilitated worker migration, resulting in increased numbers coming to Torres Strait. ${ }^{18}$ On Thursday Island, the Japanese population grew from 22 in 1890 to a peak of 619 in 1898, when, for the first time, they outnumbered the European population.

This rapid growth and dominance greatly concerned Douglas and other like-minded Queenslanders, who saw Japanese as a threat to their livelihood and to their British way of life. ${ }^{19}$ Douglas's remarks in 1895 about Japanese residing on Thursday Island are illustrative of this concern:

They have their own shops, their own boat building slip, and they are trying, they say, to establish a public house of their own it will very soon be a case, I fear, of the survival of the fittest, and if things go on as they are doing, the Caucasian will be played out. ${ }^{20}$

Although Douglas had nothing against Japanese personally, he believed they posed a danger to the European way of life on the island: 'I have really a great respect for the Japanese and a great admiration for their physical and mental capacities; all the same, I think we shall have to look out. ${ }^{.21}$ As a group, he regarded them as 'a positive menace to the White population' residing there, ${ }^{22}$ outlining his reasons as follows:

If there is one conviction, one passion, I may almost say, which is more deeply rooted in the Australian character, than another, it is that of maintaining the idiosyncrasy of the races from which we derive our origin - We must, through the length and breadth of Australia, be commandingly European. That is my conviction still, and here am I living in one of the most cosmopolitan communities in the world. This conviction arises not from any particular pride in one country, though that is not a bad thing in itself. It arises, I believe, from a fixed assurance that the best interests of Australians as a whole are bound up in the integrity and homogeneity of the people. ${ }^{23}$

So when Japanese began entrenching themselves in the pearling industry in Torres Strait in the mid-1890s, Douglas and others became alarmed.

They very soon began to evince a greater aptitude for independent enterprise than any of the other Asiatic races, and they have shown their capacity not only as seaman and divers, but also as artificers and tradesman. ${ }^{24}$ 
At every turn, Douglas warned the Government as to what was happening - the numbers of Japanese arriving and the impact their presence was having - consistently demanding action. ${ }^{25} \mathrm{He}$ complained that Japanese women were being brought to the island for prostitution and that the number of Japanese men arriving was too great to be absorbed into the local fishing industry. ${ }^{26} \mathrm{His}$ concerns, however, were ameliorated by his belief that, being fishermen, they would not settle permanently on Thursday Island, while his strong belief in liberalism admired them as 'hardworking people, tractable, inoffensive, and reasonable'. ${ }^{27}$ Douglas also believed it unfair that aliens, who would never settle permanently in Torres Strait, should be allowed to exploit the fisheries.

I hardly think that British fishermen, with all their pluck and indomitable love of freedom, would as cheerfully invite their French or Dutch neighbours to share in the privileges of their home fisheries as we do when we license Japanese or Malays to fish within the limits of our maritime boundary. ${ }^{28}$

The Queensland Government was receptive to Douglas's concerns and acted quickly, voicing opposition to the flow of migration from Japan, and appointing a commission of inquiry in March 1897, which resulted in the act being amended so that Japanese could not rent boats or be issued with boat licences. ${ }^{29}$ These restrictions, allied with the active involvement of the Japanese Government in restricting immigration to Queensland ${ }^{30}$ and the Commonwealth Government's Immigration Restriction Act of 1901, were effective in stemming the tide of Japanese to Torres Strait.

Nevertheless, resentment towards the Japanese 'invasion' took time to abate, as this 1899 observation attests:

The Japanese, despite his industry and his cleverness, is not liked and is not trusted. The race are personally agreeable, but they get everything into their own hands, both by underselling, mysterious, and unfathomable systems of combination. Japanese were first brought to Thursday Island as divers. Then they got to win boats and then combined in the ownership of boats subsequently they took to building boats, and very good boats, from schooners downwards, they do build. The 30 or 40 White men who formerly worked at boat-building and repairing work are no more. ${ }^{31}$

Douglas was satisfied that the threat had been seen off. He observed in 1901 that Japanese arrivals to the island had ceased almost entirely, resulting in the 'Japanese problem' being 'solved'. ${ }^{32}$ Despite the White Australia Policy now in force, Japanese and other non-Europeans were still needed in the pearling 
industry. Douglas knew that while 'White men can do well as divers', they refused to do this sort of dangerous work, and he therefore recognised the industry's need for Japanese, but only as 'auxiliaries'. ${ }^{33}$ For Douglas, the solution was obvious: employ Torres Strait Islanders and Papua New Guineans. ${ }^{34}$

\section{Douglas and the Chinese}

The discovery of gold on the Palmer River led to large numbers of Chinese flocking to north Queensland. In a three-week period in April 1875, 3,272 Chinese disembarked at Cooktown, the port of entry to the Palmer. ${ }^{35}$ By 1877 , there were an estimated 17,000 Chinese on the field, about 10 per cent of the entire European population of Queensland. ${ }^{36}$ As premier at this time, Douglas took action to stop the flow of Chinese miners into the colony by insisting they be quarantined, and then legislating the imposition of a $£ 10$ head tax. His attitude, and that of his compatriots, was fully in accord with the belief of the time that not only were Asian and Western values irreconcilable, but it was their duty to ensure that Queensland remained a colony true to British values and ideals.

Douglas was concerned that the Asians would dominate the north of the colony. Queenslanders were well aware of what was occurring in America, where many Chinese goldminers had settled after the California gold rushes, and were afraid that would also happen here. ${ }^{37}$ The following comment, by explorer and bushman Christie Palmerston, articulated the thoughts and fears of many colonists:

When once the Chinese swarm a goldfield, they overrun it as a horde of locusts do a wheat crop. They are of no earthly use to Queensland, which they rob annually of much wealth, without yielding any reciprocal revenue or helping to develop the productive resources of the colony. ${ }^{38}$

Queenslanders had a stake in the future of their colony, demanding the right to settle and develop the vast, sparsely populated colony as they saw fit. Above all, they wanted it peopled by men who subscribed to British values and who embraced the British way of life. As the Brisbane Courier insisted, 'Australia cannot be both Chinese and British; it must be one or the other.'39 The determination of Queenslanders to reject Chinese immigration was compared with the actions of an earlier generation of Australian colonists who refused to receive convicts. ${ }^{40}$ Not only did they believe the comparison with convict labour was apt, they believed that this was the gravest issue to have arisen in Australia since the abolition of convict transportation in $1868 .{ }^{41}$

In putting a halt to continued Chinese immigration to Queensland, Douglas had shown to what lengths he would go in order to achieve what he 


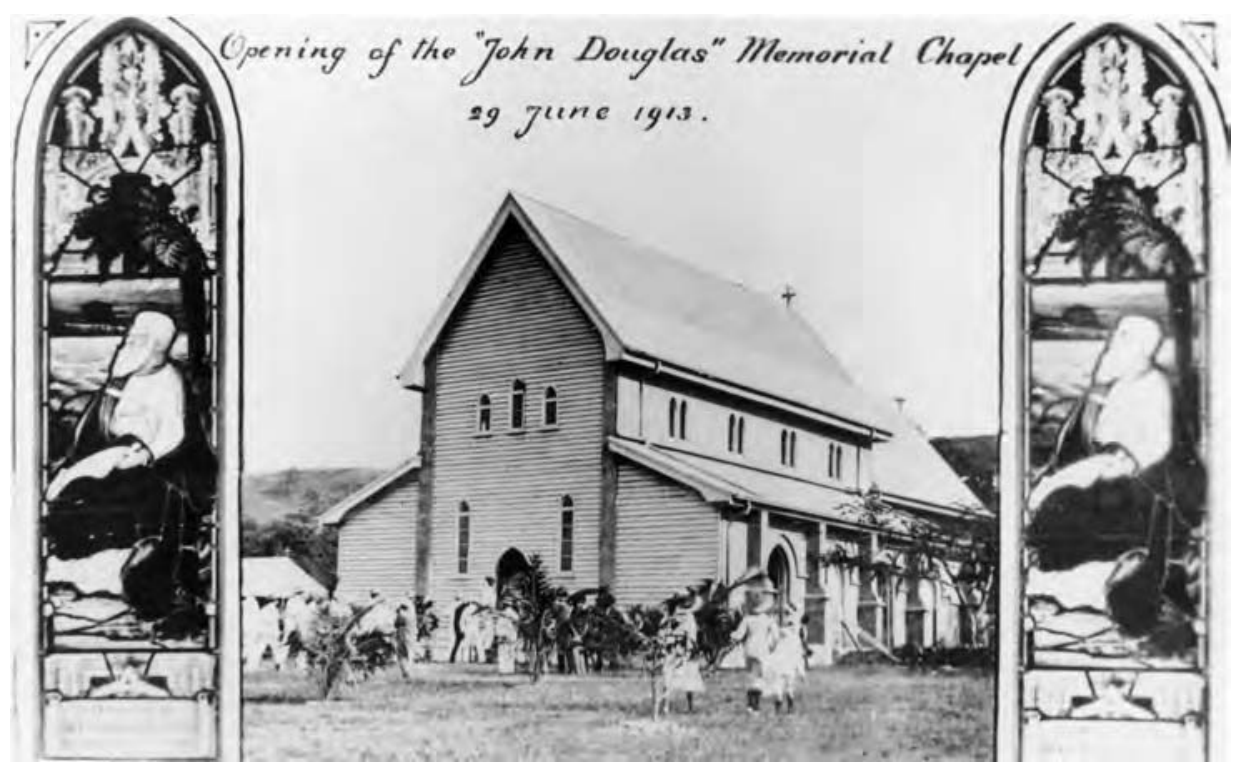

Opening of All Souls' Quetta Memorial Cathedral, Thursday Island, 29 June, 1913. Courtesy of John Oxley Library, Brisbane (Item No. 167655).

considered a just outcome for Queensland. He passionately believed in the superiority of British civilisation, British values and British institutions, and he was not prepared to have them subsumed by what he considered an alien culture. ${ }^{42}$

It is difficult to analyse this strong antipathy to Chinese using only contemporary constructions of race and racism. What to us appears as outright racism would not have been recognised as such by Queenslanders in the 1870s. Rather, there was a complex mix of racial superiority, patriotism, ${ }^{43}$ a clash of civilisations, the right to determine what sort of country Queensland would become, social Darwinism, ${ }^{44}$ and especially fear - the fear of disease, ${ }^{45}$ fear of miscegenation, ${ }^{46}$ fear of lowered living standards, fear of opium, ${ }^{47}$ and, above all, the fear of invasion. Queenslanders were strongly resolved that northern Australia would not become another Hong Kong or Singapore. They would prevent what happened in California happening here.

Douglas's attitude to Chinese on Thursday Island was very different. Being fewer in number, they were never going to threaten the European way of life on the island in the same way the Japanese did. Nevertheless, that did not mean that they were liked or respected, as attested by this 1899 Thursday Island description: 
John Chinaman is represented by about a hundred depressed and inscrutable looking persons, principally hawkers and small shopkeepers, and the keepers of boarding houses for pearlers — frowsy-looking establishments with flyblown and blood-curdling advertisements of 'ham and eggs' in the windows. Looking at the awful entrances and the glimpses afforded of the interiors, also remembering the Chinese prejudice in favour of eggs of a certain antiquity, one can judge of the quality of the provisions. But despite his subdued air and the unsubduable nature of his eggs, John on Thursday Island, as elsewhere, always gets on. He will take a little shop and display a few pennyworth of speckled fruit in his window, of which no one will be ever seen to enter and purchase, and from this mysterious trade he will rise to the boarding-house and ham and eggs business, or to the keeping of a small general store, in which no customers are ever seen either, or even to the running of a game of a much more complicated nature than Pak Ah-puh or Fan-tan, of a game (with an unpronounceable name) the principles of which are so recondite that the collective wisdom of the Thursday Island police has never yet been able to ascertain whether it be a game of chance or not and so there is no ground for a prosecution. ${ }^{48}$

Wishing to create a community on Thursday Island that would impart a civilising influence on all those who lived there, Douglas abhorred what he perceived as the pernicious effects of drink, gambling and opium, constantly preaching the need for restraint or abstinence. For Douglas, the major problem with Chinese was their opium-smoking: he considered this vice far worse than alcohol. ${ }^{49} \mathrm{He}$ also disapproved of gambling, condemning Chinese as 'insatiate gamblers'. ${ }^{50}$ By 1899 , there were two wholesale and eight retail opium dealers on the island, the regulars at the island's opium dens now including Malays and some Europeans. ${ }^{51}$

\section{Douglas and the Filipinos and Malays}

Filipinos and Malays were the other major Asian groups living and working in Torres Strait. Filipinos were known as 'Manila men', and, like Malays, were brought to Torres Strait from Singapore on three-year work agreements. ${ }^{52} \mathrm{By}$ 1885, there were 147 Filipinos in Torres Strait, but there were rarely more than 100 of them in subsequent years. Some of them settled permanently on Thursday Island, marrying women selected for them in the Philippines, and acquiring boats of their own. ${ }^{53}$ Becoming naturalised, they were seen to be the 'only fully integrated Asians' on the island. ${ }^{54}$ Nevertheless, being identified as Asian subjected them to racial hostility and misunderstanding: the Newcastle Morning Herald and Miners Advocate expressed alarm over 'hordes of Asiatic aliens $^{, 55}$ when an additional 150 Filipinos arrived on the island in 1899. 
Douglas, however, viewed Filipinos in a different light, considering them the most settled of the Asians, 'good residents who circulated their money on the island'. ${ }^{56}$

Filipinos, who were devout Catholics, took their religious celebrations very seriously, while borrowing elements from the other groups on the island, something Thomas Eykyn observed on a visit to Thursday Island about 1890:

On Christmas Eve, after dinner at the residency, numbers of Manilamen labourers came to give their Christmas performance. Chinese lanterns swung from the flagstaff on the lawn, beneath which, with the aid of the moon, they danced and sang. The band consisted of a concertina, a penny whistle, and a lovely Japanese drum. ${ }^{57}$

Douglas was impressed also with Malays, considering them to 'have furnished both good crews and good divers'. Unlike Filipinos, however, most Malays returned home at the end of their agreements. ${ }^{58}$ Douglas's views of the Malay and Filipino populations on the island were atypical of the period. Malays were widely believed to be capable of running amuck at any time, while Manila men were routinely seen as dangerous, carrying sharp knives and forever tainted with the murder of Senior Constable William Conroy by one of their number, Frank Tinyana, in $1896 .{ }^{59}$ Douglas was particularly moved by the plight of a Malay leper, consigned to the leprosarium on Dayman Island, remarking that he was 'an intelligent man, who, in spite of his troubles, contemplates life with equanimity'.60

Douglas did his best to keep the peace on the island. In 1892, he was able to observe, with some satisfaction, 'that among this motley population very fair order is maintained', with no serious crimes recorded in the previous five years. ${ }^{61}$ This state of affairs could not last forever. Early in 1901, an organised fracas occurred between the Pacific Islanders and Manila men, leaving one person dead, several seriously injured, and the shop of the leading Filipino on the island, Heriberto Zarcal, extensively damaged (see Reynaldo Ileto's Chapter Five, this volume). ${ }^{62}$ Douglas took immediate steps to prevent any further outbreak of violence, swearing in special constables and imposing a curfew, during which the police and military patrolled the streets. ${ }^{63}$

This melee was atypical: there was a surprising degree of tolerance and harmony, considering the small size of the island, its tropical climate and isolated location. Economic interdependence required a degree of cooperation between all sectors of the community, leading to the development of a cosmopolitan and relatively stable society. As Douglas proudly observed of his beloved island in 1902: 
We have all the essentials which may be regarded as appertaining to a white Australia: we have the same all-pervading British law, applicable to Asian and Australian alike, the same English language, and the same forms of social intercourse which prevail in southern Australia: our churches and schools are an exact counterpart on a small scale of what they are in Melbourne or in Brisbane. ${ }^{64}$

\section{Conclusion}

Douglas was Government Resident during the formative stages of the development of Thursday Island as a thriving multiracial community. The introduction of the Immigration Restriction Act of 1901 after Federation would forever change the nature of the fisheries in Torres Strait, changes that would inevitably affect the composition of the Thursday Island community. By the time of Douglas's death in 1904, aliens, as authorised under this act, were being brought in as indentured labour under articles and were allowed to set foot ashore for a short period only twice a year. 65

The White Australia Policy, coupled with the diminished authority of his successors, ensured that never again would they achieve their previous dominance or influence.

\section{Footnotes}

1 These words were used by James Morris, the distinguished British historian, of the annexation of the Punjab by the Raj. See Morris, J. 1979. Heaven's Command: an imperial progress.

Harmondsworth: Penguin. p. 181.

2 'As others see us'. Torres Straits Pilot and New Guinea Gazette, 30 September, 1898. p. 2.

3 Ibid.

4 'J. Douglas to the Under Secretary, Home Office, 24 January 1902.' HOM/A39/01610, Queensland State Archives (hereafter QSA).

5 For an account of this voyage, see 'Our northern outposts.' Brisbane Courier, 8 December, 1877. p. 6.

6 'As others see us'. Torres Straits Pilots and New Guinea Gazette, 23 September, 1899. p. 2.

7 'A new view of Federation: address by the Hon. John Douglas.' Telegraph, 2 October, 1896. John Douglas papers, OM89-3/Series C, news clippings and postcards, John Oxley Library, State Library of Queensland.

8 Douglas, J. 1899-1900. 'The Islands and inhabitants of Torres Strait.' Queensland Geographical Journal, 15th session. p. 35.

9 J. Douglas to his children, 19 May, 1894, copy in possession of the author.

10 'J. Douglas to Colonial Secretary, 26 October 1885.' A/443/8337, QSA.

11 'The Futami Maru.' Torres Straits Pilot and New Guinea Gazette, 14 October, 1899.

12 'J. Douglas, Report of the Government Resident at Thursday Island for 1896 and 1897.' p. 4.

'J. Douglas, Report of the Government Resident at Thursday Island for 1898.' p. 3.

13 'A charge of indecency.' Torres Strait Pilot and New Guinea Gazette, 29 January, 1898.

14 Ibid.

15 Ibid. 
16 Old Colonist. 1898. Reminiscences of Half a Century and Present-Day Politics. Rockhampton: Record Printing Company. pp. 66-7.

17 Ganter, R. 1994. The Pearl-Shellers of Torres Strait: resource use, development and decline, 1860s-1960s. Melbourne University Press. p. 100.

18 Ibid., pp. 102-4.

19 'J. Douglas, Report of the Government Resident at Thursday Island for 1892-93.' p. 3. For a reaction to the influx of Japanese, see Armstrong, J. B. 1970. 'The question of Japanese immigration to Queensland in the nineteenth century.' MA Qual. thesis, University of Queensland. pp. 63-70.

20 Douglas, J. 'Thursday Island and the Japanese.' 5 June, 1895, AD 39, Dixson Library, State Library of New South Wales.

21 Ibid.

22 'The Japanese question.' Brisbane Courier, 12 May, 1897. p. 4.

23 Ibid.

24 Douglas, J. 'Asiatic aliens in Torres Straits.' 13 July, 1895, p. 2. PRE/105, QSA.

25 Précis of papers dealing with the necessity for restricting Japanese immigration, PRE/105, QSA.

26 Ibid. He had not originally opposed the Japanese prostitutes on the grounds that they were 'clean and honest and less troublesome than the white women who had preceded them'. He soon changed his mind, however, considering them to be a corrupting and demoralising influence without which Thursday Island would be better off, and that the respectable inhabitants of Thursday Island, European and Japanese, found their antics at the Yokohama Brothel to be disgusting. He was also in no doubt that they 'are bought and sold like so many sheep and cattle'. See Armstrong, J. B. 1973. 'Aspects of Japanese immigration to Queensland before 1900.' Queensland Heritage, Vol. 2, No. 9, November. p. 5. 'J. Douglas, Report of the Government Resident at Thursday Island for 1894-95.' p. 2. 'J. Douglas, Report of the Government Resident at Thursday Island for 1896 and 1897.' p. 4.

27 Douglas, J. 'Asiatic aliens in Torres Straits.' p. 3. PRE/105, QSA.

28 'J. Douglas, Report of the Government Resident at Thursday Island for 1892-93.' p. 4. 'J. Douglas, Report of the Government Resident at Thursday Island for 1900.' p. 2.

29 'Report of the Departmental Commission on Pearl-Shell and Bêche-de-Mer Fisheries.' Queensland Votes and Proceedings, 1897, Vol. 2. pp. 1301-52.

30 See Murakami, Y. 1999. 'Civilised Asian: images of Japan and the Japanese as viewed by Australians from the early nineteenth century to 1901.' PhD thesis, University of Queensland, Chapter 5. And Willard, M. 1967. 2nd ed. History of the White Australia Policy to 1920. Melbourne University Press. pp. 116-18.

31 Torres Straits Pilot and New Guinea Gazette, 30 September, 1899. p. 2.

32 'Colour at Thursday Island.' Brisbane Courier, 3 May, 1901. p. 4. 'J. Douglas, Report of the Government Resident at Thursday Island for 1899.' p. 3. 'J. Douglas, Report of the Government Resident at Thursday Island for 1900.' p. 1. Sydney Morning Herald, 2 May, 1901. p. 4.

33 The Age, 6 September, 1902. p. 10. Douglas, J., 'Asiatic aliens in Torres Straits', p. 3.

34 'J. Douglas, Report of the Government Resident at Thursday Island for 1900.' pp. 3, 4.

35 Evans, R., K. Saunders and K. Cronin. 1988. Race Relations in Colonial Queensland: a history of exclusion, exploitation and extermination. St Lucia: University of Queensland Press. p. 255.

36 Willard, M., History of the White Australia Policy to 1920, p. 40.

37 Ibid., pp. 41-2. A United States Federal Commission inquiry into this matter had concluded that Chinese immigration to the US had been 'ruinous to our labouring classes, promotive of caste, and dangerous to free institutions'. C. S. Mein had brought this report to the attention of the Queensland Parliament, observing, 'I have read this report as testimony of the result to a civilised community of the same race as ourselves, possessing similar institutions to our own, from the coming among them of a large Chinese population, and from the unrestricted invasion of the country by an inferior race. That is what this country will arrive at, unless we take steps to protect ourselves against this invasion.' 
38 Queensland Figaro, 5 February, 1877.

39 Brisbane Courier, 31 March, 1877. p. 4.

40 Brisbane Courier, 25 April, 1877. p. 2.

41 Brisbane Courier, 8 May, 1877. p. 2.

42 Under social Darwinism, which posited that human history was progressive and full of competition, the 'yellow races' were thought to be at a lower level than that of the 'white man'. Their civilisation and culture, instead of being recognised and celebrated, was instead considered a liability, resulting in them being 'exhausted and overborne by an ancient and different civilization'. Mills, W. 1904. The Struggle for Existence. Chicago: International School of Social Economy. p. 545. These ideas were widely subscribed to in Queensland at this time (see Evans, R. et al., Race Relations in Colonial Queensland, pp. 256-7).

43 Patriotism had a somewhat different meaning in the late nineteenth century than it does now, as can be seen from this definition: 'A person's love of the social body of which he is himself a member, and which is attached to the territory he calls his country. It involves a desire to promote its welfare, a wish that it may prosper for the time being and for the future. This desire is the outcome of a variety of sentiments; of men's affection for the people among whom they live, of attachment to the places where they have grown up or spent part of their lives, of devotion to their race and language, and to the traditions, customs, laws, and institutions of the society in which they were born and to which they belong.' Westermarck, E. 2nd ed. 1917. The Origin and Development of Moral Ideas. London: MacMillan. p. 167.

44 See Evans, R. et al., Race Relations in Colonial Queensland, pp. 241-5.

45 Smallpox had recently been encountered aboard ships plying the China route, leading to mandatory 16-day quarantine for these vessels.

46 See Evans, R. et al., Race Relations in Colonial Queensland, pp. 293-9. As the Northern Miner noted on 26 May, 1877, 'There is no affinity between them and men of the Caucasian race, and miscegenation of races so physically antagonism must inevitably degrade the higher race.' Quoted in Evans, R., op. cit., p. 261.

47 Douglas considered the scourge of opium to be 'A terrible curse to a nation ... Worse even than whisky. Worse than gin or rum or brandy or any other spirits.' John Douglas to his son, Robert Douglas, 19 May, 1894, copy in possession of the author.

48 Torres Straits Pilot and New Guinea Gazette, 23 September, 1899. p. 3.

49 J. Douglas to his children, 7 September, 1893, copy in possession of the author. 'J. Douglas, Report of the Government Resident at Thursday Island for 1898.' p. 6.

50 J. Douglas to Edward Douglas, 7 October, 1894, copy in possession of the author.

51 'J. Douglas, Report of the Government Resident at Thursday Island for 1898.' p. 6.

52 Douglas, J., 'Asiatic aliens in Torres Straits', p. 1.

53 Ibid., p. 2; Douglas, J. 1902. 'Asia and Australasia.' The Nineteenth Century and After, July. p. 51.

54 Perdon, R. 1998. Brown Americans of Asia. Sydney: Manila Prints. p. 116. 'J. Douglas, Report of the Government Resident at Thursday Island for 1894-95.' p. 2. Douglas was a strong supporter of naturalisation, see 'Report of the Government Resident at Thursday Island for 1896 and 1897', p. 4.

55 Quoted in Perdon, R., Brown Americans of Asia, p. 121.

56 Douglas, J. 'Minutes of Evidence taken before the Pearl-Shell and Bêche-de-Mer Fisheries Commission.' 'Report, together with Minutes of Evidence and Proceedings, of the Commission Appointed to Inquire into the General Working of the Laws Regulating the Pearl-Shell and Bêche-de-Mer Fisheries in the Colony, 1897.' p. 2. 
57 Eykyn, T. 1896. Parts of the Pacific. London: Swan Sonnenschein. p. 99.

58 Douglas, J, 'Asiatic aliens in Torres Straits', p. 2.

59 Ibid., pp. 6-7. 'F. Urquhart to J. Douglas, 24 July 1895.' PRE/105, QSA. For details on the murder of Conroy, see 'Police Commissioner's staff files', file 300 AF [re William Conroy], A/38748, QSA. I am indebted to Anna Shnukal for alerting me to the file's existence.

60 'J. Douglas, Annual Report of the Government Resident at Thursday Island, 1890.' p. 6.

61 'J. Douglas, Annual Report of the Government Resident at Thursday Island, 1892.' p. 2.

62 'Brown and Black.' Torres Straits Pilot and New Guinea Gazette, 19 January, 1901. p. 2.

63 Ibid.; 'The pearl shelling industry.' Sydney Morning Herald, 2 May, 1901. p. 4.

64 Douglas, J., 'Asia and Australasia', p. 51.

65 'H. Milman, Report of the Government Resident at Thursday Island for 1904.' p. 6. Ganter, R., The pearl-shellers of Torres Strait, p. 107. 


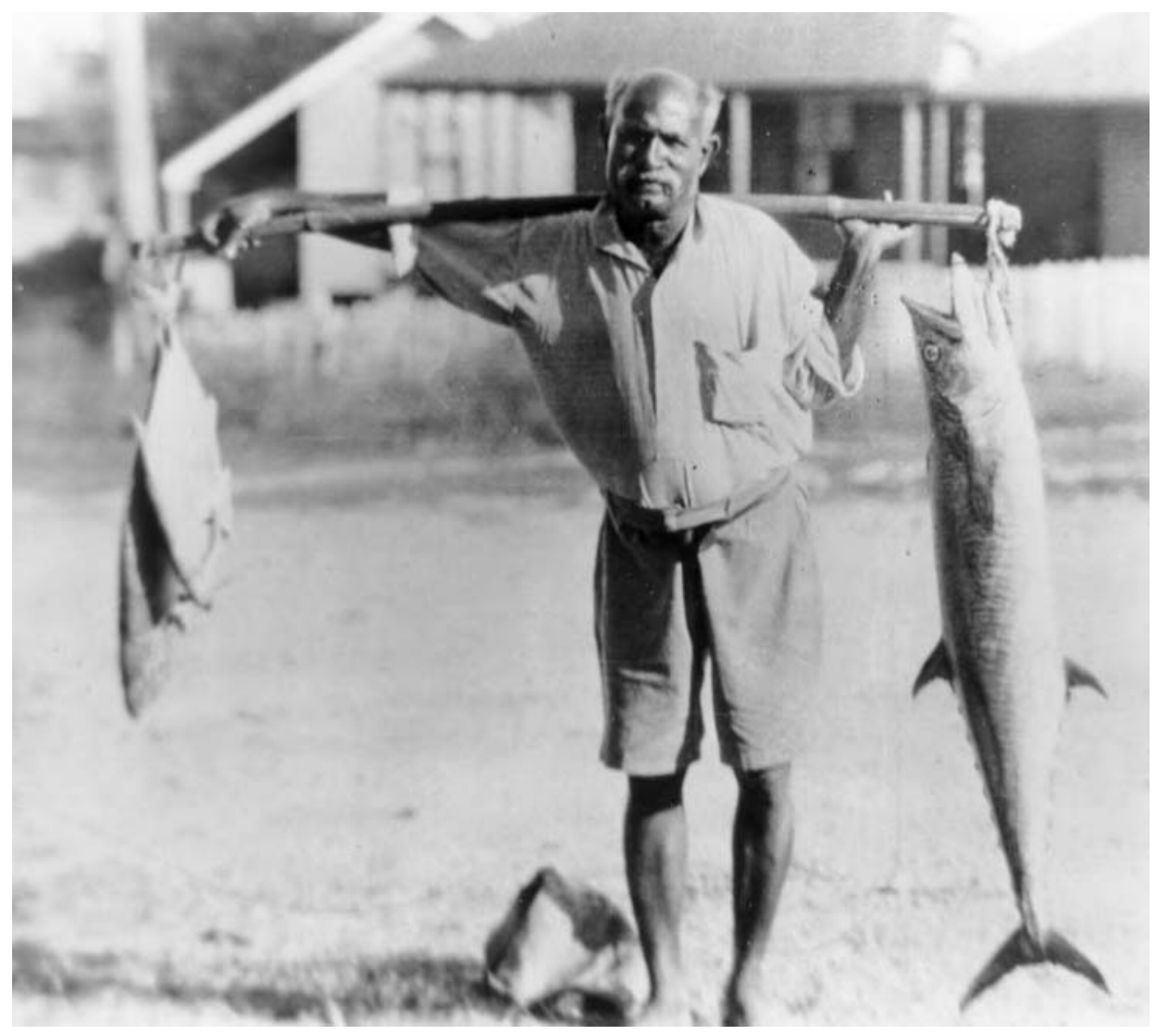

Thursday Island personalities, 1935.

Courtesy of John Oxley Library, Brisbane (Item No. 42823). 
This text is taken from Navigating Boundaries: The Asian diaspora in Torres Strait, edited by Anna Shnukal, Guy Ramsay and Yuriko Nagata, published 2017 by ANU eView, The Australian National University, Canberra, Australia.

dx.doi.org/10.22459/NB.11.2017.08 